\title{
Wiktoryn Kuczyński, Pamiętnik 1668-1737, opracowanie zbiorowe pod kierunkiem Józefa Maroszka, Bialystok 1999.
}

O istnieniu pamiętnika Wiktoryna Kuczyńskiego (1668-1738), kasztelana podlaskiego wiedziano od dość dawna. Już w roku 1893 Zygmunt Gloger na łamach czasopisma „Kronika Rodzinna” zamieścił jego streszczenie. Tam też podał informację, że oryginał pamiętnika znajdował się w bibliotece pałacu w Korczynie nad Bugiem niedaleko Drohiczyna. Nie on był jednak właściwym odkrywcą pamiętnika. Oryginał udostępnił mu Adam, hr. Starzeński, potomek pamiętnikarza. On też na szczęście skopiował rękopis pamiętnika Wiktoryna Kuczyńskiego, bowiem bibliotekę korczewską Niemcy zniszczyli w czasie drugiej wojny światowej. Wówczas też przepadł oryginał korczewski. Ta też kopia stała się podstawą omawianej edycji. Przechowywana jest obecnie w Państwowym Muzeum Historyczno-Archeologicznym w Grodnie, w Oddziale Rękopisów i Starodruków, nr 07696.

Wiktoryn Kuczyński nie był pierwszym w rodzie pomysłodawcą spisywania pamiętnika. Wiadomo, że pamiętnik pisał już jego ojciec Walenty Kuczyński. Byłaby to zatem kontynuacja tradycji rodzinnej, ale chyba też dobrego zwyczaju istniejącego praktycznie w każdym domu ziemiańskim. W czasach, kiedy nie było hipotek, o archiwa domowe dbano szczególnie starannie. Spisywano corocznie bądź codziennie w silva rerum szczegóły dotyczące gospodarstwa, interesów, umów, etc. Te zapiski niekiedy dla nas jednostajne i monotonne spełniały kapitalną rolę w każdym gospodarstwie domowym. Były pomocne przy różnego rodzaju rozrachunkach czy wyjaśnieniach dotyczących ważniejszych czynności, przede wszystkim prawnych. Pozwalały także, niekiedy po wielu latach, wrócić z dokładnością do dnia do szczegółów zawartej transakcji handlowej, cen produktów rolnych, narodzin, zgonów i małżeństw członków blizszej i dalszej rodziny oraz krewnych, znajomych i znaczących postaci w kraju bądź okolicy. Tam też wynajdywano dowody do pieniactwa, znajdowano przyczyny sporów o charta, o zgubioną rękawiczkę, etc. Informacje, suche i lakoniczne, poprzez swoją ciągłość pozwalają na odtworzenie przez potomnych obrazu stosunków społecznych, kultury, handlu i rolnictwa szlachty polskiej. Na kartach tychże pamiętników znajdujemy odbicie wydarzeń politycznych krajowych i powiatowych, wojen, i klęsk żywiołowych.

Pamiętnik Kuczyński zaczął spisywać w roku 1690, a skończył w roku swojej śmierci czyli w 1737. Pisał systematycznie rok po roku, najprawdopodobniej korzystając z notatek sporządzanych przy okazji ważniejszych wydarzeń czy czynności prawnych. Informacje są suche, lakoniczne, pozbawione jakichkolwiek emocji czy komentarza do zapisywanych wydarzeń. Nie pisał wszak Kuczyński po to aby ułatwić życie historykom, a po to aby dopomóc własnej pamięci wtedy, gdy ona zawieúzie i wówczas sięgnąć do słowa pisanego precyzyjnie informujące- 
go o zaszłych czynnościach. Dlatego też pamiętnik Kuczyńskiego to przede wszystkim świadectwo obrotu ziemią, sukcesywnego skupowania wiosek i folwarków, zastawów, dzierżaw, pożyczania pieniędzy i skrupulatnego rozliczania wierzycieli. Przy tym też informacje o miejscu przechowywania odnośnych dokumentów. Pisał też Kuczyński o transakcjach handlowych, przede wszystkim zbożem. Zboża sprzedawał dużo i dlatego też skrupulatnie zapisywał ceny obowiązujące wówczas w Gdańsku i cenę jaką jemu udało się uzyskać. Z racji na uprawę zboża niekiedy notował też warunki pogodowe, zwłaszcza wiosenne powodzie, wielkości opadów czy letnie susze, choć informacje pogodowe nie występują u niego takiej skali jak u bezpośredniego poprzednika po piórze Jana Antoniego Chrapowickickiego. Występują też informacje o pomorach dziesiątkujących ludność Podlasia. Często pojawiały się one przy okazji innych klęsk nawiedzających okolicę. Przyszło bowiem Kuczyńskiemu żyć w czasach niespokojnych, a odbicie tych wydarzeń znalazło miejsce na kartach pamiętnika. Odnajdujemy tam opisy burzliwej elekcji po śmierci Jana III, kiedy to o tron Rzeczypospolitej rywalizowali: książę saski August Wettyn i francuski książę de Conti (s. 22-23), czy równie burzliwej elekcji po śmierci Augusta II i o działaniach zbrojnych na przedpolach Warszawy (s. 61), a także echa wojny domowej na Litwie zakończonej bitwą olkiennicką (s. 28). Przede wszystkim jednak opisywał Kuczyński uciążliwości wojny północnej na Podlasiu: bitwy, potyczki, permanentne przemarsze wojsk, kontrybucje i rekwizycje. Pamiętnikarz, jak się wydaje, był zwolennikiem Stanisława Leszczyńskiego i nawet gościł go w październiku 1708 roku w rodzinnym Klukowie (s. 39). Z racji na własną działalność publiczną połączoną z rozlicznymi wyjazdami opisywał też Kuczyński swoją działalność na sejmiku drohickim, sprawowane funkcje poselskie na sejmie w Warszawie czy Grodnie, czy też działalność deputacką na Trybunale w Piotrkowie czy Lublinie. Zadziwiające, ale nie zawarł Kuczyński w pamiętniku żadnego własnego komentarza do opisywanych wydarzeń. Brak najmniejszej próby oceny. Ze spraw osobistych przede wszystkim skrupulatnie notuje własne kolejne awanse w karierze urzędniczej. Niewiele pisze na temat wydarzeń rodzinnych. Pilnie zapisuje tylko niemalże coroczne narodziny dzieci, czasami ich zgony (dojrzały wiek osiągnęły dwie córki i pięciu synów), potem wydawanie córek za mąż i narodziny wnuków, etc. Notuje też zgony znaczniejszych osób z sąsiedztwa i z kraju. Są to również informacje jednozdaniowe, nieopatrzone jakimkolwiek komentarzem. Bardzo precyzyjne zapisywał działy majątkowe między swych synów. Brak natomiast jakichkolwiek informacji na temat życia codziennego czy obyczajów. Rzadko też pisał o swoim zdrowiu, najprawdopodobniej niezłym, skoro dożył 71 lat. Nie ma też wiadomości na temat działalności fundacyjnej Kuczyńskiego, choć działalność ta pochłaniać przecież musiała ogromne sumy. Szczegółowo piszą o tym wydawcy we wstępie do niniejszego tomu.

Autor pamiętnika, Wiktoryn Kuczyński, h. Ślepowron, był synem Walentego Kuczyńskiego, łowczego drohickiego (1661-80) a późniejszego podsędka drohickiego (1682-90) i jego drugiej żony Joanny Niemierzanki, stolnikówny podlaskiej. Już Walenty Kuczyński dzięki zdolnościom i niezwykłej gospodarności doszedł do znacznej fortuny, co pozwoliło mu na skupienie Kuczyna i wielu okolicznych majątków. Zaś jego syn, a autor naszego pamiętnika dzięki stanowisku, majątkowi i dużym dochodom wybił się na pierwszą po Branickich i Ossolińskich pozycję na Podlasiu i zapewnił znaczne stanowisko swej linii mało dotychczas znanego rodu. Był też Wiktoryn Kuczyński człowiekiem wykształconym jak na owe czasy. Wacław Szczygielski, autor biogramu Kuczyńskiego w PSB (t. XVI, z. 1, s. 96) twierdzi, że przyszły pamiętnikarz kształcił się za granicą. Z samego zaś pamiętnika wynika, że kształcił się przede wszystkim w krajowych kolegiach 
jezuickich. Początkowo w pobliskim Drohiczynie, później zaś w istniejącym od 1616 roku Kolegium Łomżyńskim. W latach 1682-1683 naukę kontynuował najprawdopodobniej w Reszlu i Braniewie na Warmii. Miasta te od 1466 roku pozostawały w składzie Rzeczypospolitej i tym samym o żadnym zagranicznym kształceniu Kuczyńskiego mówić chyba nie można. Nazwy miejscowości w pamiętniku co prawda są zniekształcone, bądź przez niego samego bądź też przez kopistę i brzmią: Resel $i$ Brącberk (odpowiednio w języku niemieckim: Rossel $i$ Braunsberg). Wyjaśnienie podane przez wydawców, że Brącberk to Braniewo wydaje się zasadne, gdyż zarówno w Reszlu jak i w Braniewie istniały kolegia jezuickie. Zwłaszcza to ostatnie kolegium szczyciło się wysokim poziomem nauczania i kształciło wiele późniejšych wybitnych osobistości Rzeczypospolitej. W 1684 roku wyjechał do Lublina aby zgłębiać filozofię, następnie zaś w Krakowie kształcił się w różnych naukach. Zdobyte wykształcenie, zwłaszcza znajomość łaciny, znacznie ułatwiły mu późniejszą błyskotliwą karierę urzędniczą. Prawa polskiego uczył się jednak dopiero w kancelarii drohickiej. Miał też Kuczyński protektora i to nie byle jakiego, bo Karola Stanisława Radziwiłła, późniejszego kanclerza litewskiego, właściciela Białej Radziwiłłowskiej (ob. Podlaskiej). Dzięki jego protekcji został w 1687 roku susceptantem grodzkim i tegoż samego roku instygatorem Trybunału Piotrkowskiego, a w 1691 roku sędzią deputatem skarbowym drohickim a w następnym roku łowczym mielnickim. Z tą też ziemią podpisał elekcję Augusta II, ale w czasie wojny północnej opowiedział się po stronie Stanisława Leszczyńskiego, którego w 1708 roku przyjmował w Klukowie. W 1710 roku na mocy konfederacji sandomierskiej uznał jednak Augusta II. W 1717 roku z ramienia sejmu niemego wszedł w skład sądu przeciwko adherentom szwedzkim. Kilkakrotnie był deputatem podlaskim na Trybunał Koronny, a w 1730 roku posłował z Podlasia na sejm grodzieński. Ukoronowaniem jego kariery urzędniczej było otrzymanie w tym samym roku kasztelani podlaskiej. Jednakże trzy lata później znowu poparł, wraz z synami, Leszczyńskiego, czym naraził swoje dobra na dewastację a syna Mikołaja na areszt rosyjski.

Opublikowany tekst pamiętnika Kuczyńskigo zawiera nie tylko jego pełny tekst ale również cztery aneksy dodane przez kopistę Adama Starzeńskiego i dwa aneksy dodane przez wydawców. Przedstawiają się one następująco: Aneks pierwszy to dwa Memoryaty pótroczne gospodarstwa ordynaryjnego gdzie znajdowały się zalecenia dotyczące kolejnych prac w gospodarstwie w ciągu całego roku (ss. 66-70). Co prawda aneks pochodzi od kopisty, ale wydaje się, że Wiktoryn Kuczyński również był dobrym gospodarzem, o czym świadczy choćby awans społeczny jego rodziny nie tylko w hierarchii urzędniczej ale też majątkowej. W jego bibliotece znajdowało się bowiem dzieło podstawowe wówczas przy właściwym prowadzeniu gospodarstwa czyli Jakuba Kazimierza Haura Ekonomika ziemiańska generalna (1675) bądź Ziemiańska generalna ekonomika (1679), (w tekście aneksu: Generalna ekonomia, nie wiadomo zatem o które z tych dzieł chodzi) oraz tegoż autora Skład albo skarbiec znakomitych sekretów ekonomiej ziemiańskiej (1693). Dzieła te w drugiej połowie XVII wieku cieszyły się w Koronie ogromną popularnością. Zawierały bowiem wykład gospodarstwa wiejskiego ukazanego głównie od strony techniczno-gospodarczej oraz organizacji i administracji dóbr. Aneks drugi ma charakter epizodyczny i dotyczy dziejów Ossolińskich w XVII wieku (s. 71). Następny, niezwykle interesujący aneks to Kilka danych o gospodarstwie pańszczyźnianem (ss. 72-75), sporządzony chyba przez Adama Starzeńskiego a dotyczący sposobów uzyskiwania jak największych dochodów z gospodarstwa, m.in. dbałości o największy kapitał każdego szlachcica czyli o chłopa. Z aneksu czwartego poświęconego rezydencji pamiętnika (s. 7677) 
wynika, że ten mieszkał w Klukowie do 1723 roku, potem w Stredyni do 1728 roku, poczym przeniósł się do Korczewa gdzie zmarł w 1737 roku. Aneks piąty pochodzący od wydawców zawiera relację z pogrzebu pamiętnikarza w kościele drohickim (s. 78-87). Bardzo ciekawa jest też zamieszczona przez wydawców korespondencja z lat 1938-1939 między Michałem Starzeńskim (synem Adama Starzeńskiego), Janiną Studnicką, dyrektorką Archiwum Państwowego w Grodnie w 1939 roku a Janem Glinką (s. 88-96). Z korespondencji tej wynika, że w połowie XIX wieku archiwum Kuczyńskich weszło w skład archiwum Starzeńskich a to poprzez Barbarę z Kuczyńskich, żonę Michała Starzeńskiego starosty brańskiego. To też archiwum hr. Michał Starzeński postanowił przekazać w formie depozytu do Archiwum Miejskiego w Białymstoku. Materiały zostały przewiezione z Pietkowa do Białegostoku 28 grudnia 1938 roku. Wraz z archiwaliami trafiły tam równie obrazy Starzeńskich i dwa pamiętniki: Michała Starzeńskiego, starosty brańskiego i Wiktoryna Kuczyńskiego, kasztelana podlaskiego. W związku z trudnościami jakie wystąpiły przy powoływaniu Archiwum Miejskiego w Białymstoku, archiwalia w końcu sierpnia 1939 roku przewiezione zostały do Archiwum Państwowego w Grodnie.

Publikacja opatrzona została fotografiami barwnymi i czarno-białymi przedstawiającymi zarówno rodzinę Kuczyńskich jak i Starzeńskich oraz fotografie budowli będących fundacjami pamiętnikarza bądź w jakiś sposób związanymi z jego działalnością. Całość wydana została niezwykle starannie, opatrzona indeksami: geograficznym i osobowym oraz całą serią szczegółowych przypisów. Dodając jednakże łyżkę dziegciu do tych pochwał, wydaje się, iż zasadne byłoby umieszczenie, wzorem innych wydawców, we wstępie do zasadniczego tekstu pamiętnika przede wszystkim poszerzonej biografii pamiętnikarza, zwłaszcza, że jego biogram w PSB jest niezwykle lakoniczny.

Niemniej niniejsza publikacja stanowi bardzo ważą pozycję na rynku edytorskim, zwłaszcza, że dotychczas pozostawała praktycznie nieznana i tym samym nie była wykorzystywana przez polskich historyków. 